\title{
Mirror Imaginary Movement Disorder and Pachygyria Association: Case Report
}

\author{
Ayna Hayali Hareket Bozukluğu ve Pakigiri Birlikteliği: \\ Olgu Sunumu
}

\author{
Yusuf Ehi1 ${ }^{1}$, Sefer Üstebay², Döndü Ülker Üstebay², Yunus Y1lmaz², Sunay Sibel Karayol${ }^{3}$ \\ ${ }^{1}$ Kafkas University Faculty of Medicine, Department of Neurology, Kars, Turkey \\ 2Kafkas University Faculty of Medicine, Department of Pediatry, Kars, Turkey \\ ${ }^{3}$ Kafkas University Faculty of Medicine, Department of Radiology, Kars, Turkey
}

\begin{abstract}
Mirror imaginary movement disorders are a group of syndromes characterized by automatic reflex mimicking of voluntary movements on the contralateral side. Two hypotheses for these symptoms are currently accepted: abnormal development of the ipsilateral corticospinal tract and transcallosal inhibition deficiency. Pachygyria refers to a decreased number of gyri divided with flat and superficial cerebral cortex sulci. We found pachygyria on cranial imaging of a boy aged 8 years who made similar movements with the one hand while writing with the other hand at presentation. Hence, pachygyria may play a role in mirror imaginary movement disorders.
\end{abstract}

Keywords: Mirror imaginary, movement disorder, pachygyria

Öz

Ayna hayali hareket bozuklukları, istemli hareketlerin kontralateral tarafta istemsiz olarak taklit edilmesiyle karakterize semptomlar topluluğudur. Patofizyolojisinde ipsilateral kortikospinal traktın anormal gelişimi ve transkallozal inhibisyon eksikliği hipotezleri kabul edilmektedir. Pakigiri serebral korteksin düz ve yüzeysel sulkuslarla ayrılmış, azalmış girus sayısını ifade etmektedir. Bir eliyle yazı yazarken diğer eliyle de benzer hareketler yapması şikayeti ile tarafımıza başvuran 8 yaşındaki erkek olgunun yapılan kranyal görüntülemesinde pakigiri tespit edilmiştir. Organik, psikolojik ve sosyolojik sorunlara yol açabilecek bu bozukluğun pakigiri ile birlikteliği literatürde nadir görüldüğü için sunulmuştur.

Anahtar Kelimeler: Ayna hayali, hareket bozukluğu, pakigiri

\section{Introduction}

In mirror imaginary movement disorders, voluntary movements by one half of the body are reflexively mimicked by the corresponding muscles in the other half of the body. These movements usually occur in the distal portion of the upper extremities, such as the wrist and fingers. Mirror imaginary movement disorders are rare (1). There are two current hypotheses for these disorders: abnormal development of the ipsilateral corticospinal tract and transcallosal inhibition deficiency (2). Except for cases are associated with congenital malformations, cases after early unilateral lesions of the motor tracts were also reported (3). Treatment is usually not required in early childhood, and symptoms usually disappear after the first 10 years of life.

Pachygyria refers to a decreased number of gyri divided with flat and superficial cerebral cortex sulci. Pachygyria usually develops in cases of cortical organization and neuronal migration anomalies (4). We present a patient who presented with a mirror

Address for Correspondence/Yazışma Adresi: Yusuf Ehi MD, Kafkas University Faculty of Medicine, Department of Neurology, Kars, Turkey Phone: +905326647768 E-mail: yusufehi@windowslive.com

Received/Geliş Tarihi: 31.07.2015 Accepted/Kabul Tarihi: 23.12.2015

${ }^{\circledR}$ Copyright 2017 by Turkish Neurological Society

Turkish Journal of Neurology published by Galenos Publishing House. 
imaginary movement disorder and exhibited pachygyria on cranial imaging.

\section{Case Report}

A boy aged 8 years made similar movements with the left hand while writing with the right hand at presentation. The symptoms had been present for approximately 3 years. The boy had difficulty writing, and school performance over the prior year had decreased due to gradually-increasing symptoms. There was no genetic kinship between the mother and father, and nothing of significance was found in the prenatal and postnatal history. Anthropometric measurements were within normal percentile values. A physical examination revealed that one hand involuntarily accompanied the fine motor movements of the other hand. Mental and motor development and other examination findings were normal. All test results (hemogram, biochemistry, thyroid function tests, urogram) were normal. No pathology was found in the cervical graphs, but pachygyria was detected in a cranial magnetic imaging (CMR) examination (Figure 1). Electroencephalography (EEG) revealed age-appropriate basal activity with no pathology. Electromyography (EMG) revealed motor unit potentials in contralateral homologous muscle groups with voluntary contraction of distal hand muscles. The patient was diagnosed as having mirror imaginary movement disorder and pachygyria as a result of the history, examination, CMR, and EMG.

\section{Discussion}

The cause of imaginary mirror movement disorder during childhood is uncertain. However, it is thought that the ipsilateral corticospinal tract activates during voluntary movements and that this activation is not inhibited by the corpus callosum (5). The disorder also can occur due to the abnormal development of the ipsilateral corticospinal tract, as seen in Klippel-Feil syndrome (6). The amplitudes of the reflexive movements are lower than those of the voluntary movements and increase with effort (7). In our patient, EMG examination revealed motor unit potentials in contralateral homologous muscle groups with voluntary

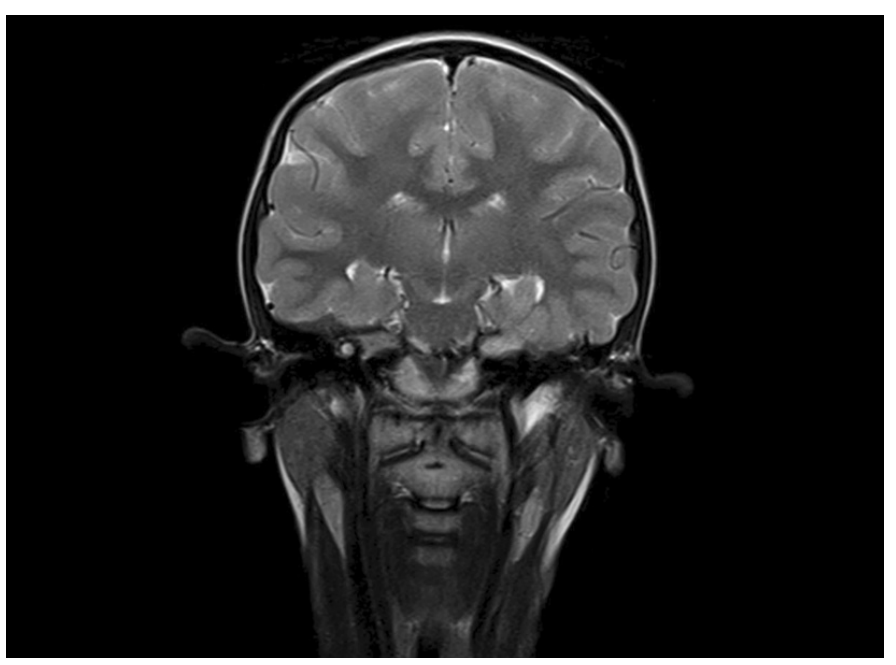

Figure 1. Pachygyria contraction of distal hand muscles. The amplitudes of these movements were lower than those of the voluntary movements. The association of mirror imaginary movement disorders with Kallman syndrome, diastomyelia, cervical meningocele, tethered spinal cord, Chiari Malformation, corpus callosum agenesis, basilar invagination, chondrodystrophy, Usher's syndrome, epilepsy, dystonia, stroke, diabetes insipidus, phenylketonuria, intracranial tumor, and many developmental defects have been identified $(3,8,9,10)$. Mirror imaginary movement disorders also occur due to improper synapse formation after acquired or degenerative neurologic disorders (11). Nothing of significance was found in our patient's hemogram, urogram, biochemical testing, or cervical graph imaging; neurologic and phsical examination was normal. The EEG examination revealed that the patient's basal activity was consistent with his age and no epileptic activity was present. Nothing of significance other than pachygyria was found in the CMR examination. Patients with cortical gyral abnormality mostly present with epilepsy and mental retardation, although the duration and severity of the symptoms vary. The clinical course of patients with a severe neuronal migration anomaly is well-defined, but information on the clinical features of focal pachygyria is inadequate (12). Mirror imaginary movement disorders are rarely seen in the clinic but can cause falling and injuries, as Regli et al. (13) reported for an 11-year-old boy who was pole climbing in a physical education class. The disorders can cause contractions with severe pain in the left shoulder and elbow during writing with the right hand, as Cincotta et al. (14) reported for a 15-year-old girl. These symptoms can also have important consequences such as decreased school performance, as in our case.

Pachygyria cases associated with congenital mirror imaginary movement are rare in the literature. Although clinical pictures accompanying pachygyria are usually reported as epilepsy and mental retardation, various malformation syndromes have also been identified (9). Kaşıkçı et al. (15) identified mirror movements during the examination of a 21-year-old male patient who presented with weakness and found polymicrogyria and corpus callosum hypoplasia during MRI imaging. The authors concluded that mirror movements could occur when deterioration in transcallosal inhibition on the side affected with polymicrogyria was coupled with an increase in the activity of ipsilateral corticospinal tracts on the opposite side (15). In our patient, the mirror movements were likely caused by the combination of pachygyria, which occurred due to cortical disorganization, and the related defect in transcallosal inhibition. These led to an increase in ipsilateral corticospinal tract activity in the contralateral hemisphere as a result of the plasticity of the brain.

In conclusion, diagnosing mirror imaginary movement disorders is only possible by using basic methods such as reviewing patient history and physical examination. The disorders' symptoms may lead to organic, physiologic and sociologic problems for the patients.

\section{Ethics}

Informed Consent: Consent form was filled out by all participants.

Peer-review: Externally peer-reviewed.

\section{Authorship Contributions}

Concept: Yusuf Ehi, Design: Yusuf Ehi, Data Collection or Processing: Yusuf Ehi, Analysis or Interpretation: Yusuf Ehi, 
Literature Search: Yusuf Ehi, Sefer Üstebay, Döndü Ülker Üstebay, Yunus Yımaz, Sunay Sibel Karayol, Writing: Yusuf Ehi.

Conflict of Interest: No conflict of interest was declared by the authors.

Financial Disclosure: The authors declared that this study received no financial support.

\section{References}

1. Nadkarni NA, Deshmukh SS. Mirror movements. Ann Indian Acad Neurol 2012;15:13-14.

2. Krams M, Quinton R, Ashburner J, Friston KJ, Frackowiak RS, Bouloux PM, Passingham RE. Kallmann's syndrome: mirror movements associated with bilateral corticospinal tract hypertrophy. Neurology 1999;52:816822.

3. Müller K, Kass-Iliyya F, Reitz M. Ontogeny of ipsilateral corticospinal projections: a developmental study with transcranial magnetic stimulation. Ann Neurol 1997;42:705-711.

4. Kanatani S, Tabata H, Nakajima K. Neuronal migration in cortical development. J Child Neurol 2005;20:274-279.

5. Canpolat M, Çelik İ, Doğanay S, Gumus H, Per H. Mirror Movement in an Isolated Case and in a Case with Klippel-Feil Syndrome. J Clin Anal Med 2013;4(Suppl 2):184-186.
6. Güner S, Şahan HM, Ceylan MF, Dönmez FY, Şirikçi A. A Case of KlippelFeil Syndrome Causing a Mass Appearance in the Nape. J Clin Anal Med 2013;4:236-238.

7. Cox BC, Cincotta M, Espay AJ. Mirror movements in movement disorders: a review. Tremor Other Hyperkinet Mov (NY) 2012;2.

8. Mayston MJ, Harrison LM, Quinton R, Stephens JA, Krams M, Bouloux PM. Mirror movements in X-linked Kallmann's syndrome. I. A neurophysiological study. Brain 1997;120:1199-1216.

9. Erdinçler P. Cervical cord tethering and congenital mirror movements: is it an association rather than a coincidence? Br J Neurosurg 2002;16:519-522.

10. Aysun S. Ayna Hayali Hareketler. Türkiye Klin Pediatr Bilim Derg. 2006;2:35-36.

11. Verma R, Dixit PK, Lalla R, Singh B. Mirror movements in progressive hemifacial atrophy. Ann Indian Acad Neurol 2015;18:246-248.

12. Yılmaz Ö, Yaman M, Altan BY, Haktanır A. Pachygyria associated with congenital mirror movements. Parkinson Hast Hareket Boz Der 2006;9:114-117.

13. Regli F, Filippa G, Wiesendanger M. Hereditary mirror movements. Arch Neurol 1967;16:620-623.

14. Cincotta M, Borgheresi A, Balzini L, Vannucchi L, Zeloni G, Ragazzoni A, Benvenuti F, Zaccara G, Arnetoli G, Ziemann U. Separate ipsilateral and contralateral corticospinal projections in congenital mirror movements: Neurophysiological evidence and significance for motor rehabilitation. Mov Disord 2003;18:1294-1300.

15. Kaşıkçı T, Yücel M, Yozgatlı G, Kütükçü Y, Odabaşı Z. Coexistence of mirror movements and polymicrogyria. Turk J Neurol 2010;16:199-202. 